\title{
Prevalence of ketosis in dairy herds in Marmara, Aegean and Mediterranean regions of Turkey
}

\author{
Sezgin ŞENTÜRK, Hüseyin CİHAN, Zafer MECíTOĞLU, Serkan ÇATIK, Gülşah DEMİR AKGÜL, \\ Sevim KASAP, Onur TOPAL
}

Uludağ University, Faculty of Veterinary Medicine, Department of Internal Medicine, Görükle, Bursa, Turkey.

Summary: Increasing energy demands of high-yielding dairy cow in postpartum period results almost always with negative energy balance (NEB). According to the degree of NEB, dairy cows could suffer from clinical or subclinical ketosis. The aim of the presented study was to evaluate the incidence and difference between incidences of clinical and subclinical ketosis in three regions with highest cattle population in Turkey; Marmara, Aegean and Mediterranean regions. Cattle $(n=980)$ from three regions $(2$ farms from each region) were selected for the study. Milk yields, management and feeding factors of all farms were similar. Blood samples were collected on days 14-21 and sixth week after calving. Blood beta hydroxybutyric acid (BHBA) and glucose levels were measured. Cows with serum BHBA $>1.2 \mathrm{mmol} / \mathrm{l}$ and negative urine ketone test were designated as suffering subclinical ketosis (SCK). Cows with serum BHBA > $1.2 \mathrm{mmol} / \mathrm{l}$, positive urine test and clinical findings such as anorexia, fatigue, depression, constipation and decrease in contractions of rumen were designated as suffering clinical ketosis (CK). Animals without any clinical finding and serum BHBA levels lower than $1.2 \mathrm{mmol} / \mathrm{l}$ at the time of sampling were designated as healthy. In Mediterranian region, $12(3,8 \%)$ and $46(14,8 \%)$ of 315; in Aegean region, 24 (7,3\%) and $54(16,6 \%)$ of 325, and in Maramara region, $33(9,7 \%)$ and 76 $(22,3 \%)$ of 340 cows were suffered from CK and SCK respectively in postpartum period. Blood glucose levels of CK cows was lower than SCK cows and blood glucose levels of both types of ketosis were lower than healthy animals in animals from all three regions. The results of the presented study indicate that incidence of CK and SCK is much higher than average incidence rates in other surveys. Especially incidence higher than $20 \%$ in Marmara region demonstrates that there are crucial errors in management and feeding in that region.

Keywords: Beta hydroxybutyric acid, cow, ketosis, negative energy balance.

\section{Türkiye'deki Marmara, Ege ve Akdeniz bölgelerinde bulunan süt sığırı işletmelerinde ketozis prevalansi}

Özet: Postpartum dönemde yüksek süt verimli ineklerde artan enerji gereksinimi neredeyse her zaman negatif enerji dengesi (NED) ile sonuçlanır. NED’nin derecesine göre süt sığırlarında klinik veya subklinik ketozis meydana gelebilir. Sunulan çalışmanın amacı Türkiye'de en çok sığır popülasyonunun bulunduğu üç bölgede; Marmara, Ege ve Akdeniz'de ketozis ve subklinik ketozis insidansı ve insidanslar arasındaki farkı değerlendirmekti. Çalışma için sığırlar (n: 980) üç bölgeden (her bölgeden 2 çiftlik) seçildi. Süt verimleri, yönetim ve beslenme faktörleri bütün çiftliklerde benzerdi. Kan numuneleri postpartum 14-21. günlerde ve 6 . haftada alındı. Kan Beta Hidroksi Bütirik Asit (BHBA) ve glukoz seviyeleri ölçüldü. Serum BHBA seviyesi > 1.2 mmol/1 ve idrar keton testi negatif olan inekler subklinik ketozis (SKK), serum BHBA > $1.2 \mathrm{mmol} / \mathrm{l}$ ve idrar testi pozitif, anoreksi, halsizlik, depresyon, konstipasyon ve rumen kontraksiyonu azalmış olan inekler klinik ketozis (KK) olarak belirlenmiştir. Herhangi bir klinik bulgu göstermeyen ve örnekleme sırasında serum BHBA seviyesi $1.2 \mathrm{mmol} / \mathrm{l}$ 'den düşük hayvanlar sağlıklı olarak belirlenmiştir. Akdeniz bölgesinde postpartum dönemdeki 315 inekten 12'si (\%3,8) ve 46's1 (\%14,8); Ege bölgesinde 325 inekten 24'ü (\%7,3) ve 54'ü $(\% 16,6)$ ve Marmara bölgesinde 340 inekten $33(\% 9,7)$ ve 76 's1 $(\% 22,3)$ sirası ile KK ve SKK'li olarak tespit edildi. KK'li ineklerde kan glukoz seviyesi SKK'li ineklerden daha düşüktü ve üç bölgede de her iki tip ketozisli hayvanların kan glukoz seviyesi sağlıklı hayvanlardan daha düşüktü. Sunulan çalışmanın sonuçları göstermektedir ki KK ve SKK insidansı diğer araştırmalardaki ortalama insidanstan daha yüksektir. Özellikle Marmara bölgesinde insidansın \% 20'den daha yüksek olması gösteriyor ki bu bölgede önemli beslenme ve yönetim hataları bulunmaktadır.

Anahtar sözcükler: Beta hidroksi bütirik asit, inek, ketozis, negatif enerji dengesi.

\section{Introduction}

The rapidly rising energy requirement of the recently calved cows coincides with the time when dry matter intake is reduced. In order to sustain high levels of milk production; high yielding dairy cows in that period mobilize fat from body stores which results with elevated concentration of circulating ketone bodies in early lactation. When carbohydrate levels are limited, ketone 
bodies are used by peripheral tissues as a source for energy. However, as the levels of circulating ketone bodies increase and sustains at elevated levels, a state that is known as ketosis occurs. Subclinical ketosis of dairy cattle is a condition characterized with the presence of excess levels of circulating ketone bodies in the absence of clinical signs of ketosis except decreased milk yield. Beta hydroxybutiric acid (BHBA) is used for determination of ketotic status of dairy cows as it is the most stable ketone body. Threshold level of $1.2 \mathrm{mmol} / \mathrm{L}$ is used for evaluation of ketotic state, cows with levels higher than that and which did not show typical signs of ketosis are suffering subclinical ketosis (19). The main economic impact of subclinical ketosis is related with decreased milk yield $(5,20)$ and increase in the average calving interval (12). However it is also well documented that incidence of peri parturient diseases such as displacement of abomasum (9), metritis $(5,6,7)$ and mastitis $(17,27,29)$ is higher in cows with elevated BHBA levels.

In recent years, the number of large dairy farms in Turkey increased significantly. The incidence of metabolic diseases increased concurrently with increased number of large dairy farms. Especially, primary clinical ketosis and subclinical ketosis that occurs as a result of negative energy balance and yield losses associated with this problem is one of the major health problems that Turkish dairy farms are facing.

The aim of the presented study is to demonstrate the incidence of primary ketosis and subclinical ketosis in three major regions with highest numbers of large farms in Marmara, Aegean and Mediterranean regions.

\section{Materials and Methods}

The study was performed in six different dairy farms located in Mediterranean, Aegean and Marmara regions. Totally 980 milking cows were the materials of the study (315 milking cows in two different farms in Mediterranean region, 325 milking cows in two different farms in Aegean region, and 340 milking cows in two different farms in Marmara region). Fresh cows in farms in the scope of work were milked three times a day. The average daily milk was similar in all the farms. The average daily milk productions in two different farms in the Mediterranean were determined as $31.2 \pm 3.24 \mathrm{~kg}$, and $33.1 \pm 3.68 \mathrm{~kg}$, respectively. Similarly, the average daily milk in two different farms in the Aegean was 30.5 \pm 4.11 $\mathrm{kg}$, and $31.2 \pm 3.57 \mathrm{kilograms}$, respectively. Also, average of daily milk of in two different farms in the Marmara region was determined as $30.1 \pm 2.24$ and $33.2 \pm 3.14$ kilogram, respectively, during the study period.

Animal selection criteria: For subclinical ketosis; except the low milk yield, clinically healthy animals on postpartum days 14 to 21 were selected for the study.
Animals with serum BHB level $>1.2 \mathrm{mmol} / \mathrm{l}$ (22) and negative urine ketone test were classified as subclinical ketosis.

For primary clinical ketosis; animals on postpartum days 14 to 21 showing signs of primary ketosis, such as decrease in milk yield and anorexia, fatigue, depression, constipation, decrease in contractions of rumen positive urine test and serum BHB level higher than $1.2 \mathrm{mmol} / \mathrm{l}$ were categorized as suffering clinical ketosis.

Animals suffering from diseases that cause secondary ketosis such as displacement of abomasum, mastitis, metritis, reticuloperitonitis traumatica (RPT) and lameness were excluded from the study.

For healthy animals; cattle in days between 14 and 21 postpartum that were detected to be healthy after clinical examination were enrolled as healthy control group of the study. Urine ketone tests of animals in these groups were negative and serum BHB levels were lower than $1.2 \mathrm{mmol} / 1$.

Blood sampling for the measurement of BHB and glucose: Four to six hours after the morning feeding, the blood samples were collected from the coccygeal vessels at the same time using vacuum tubes with clot activator and gel for serum separation (Becton Dickinson and Company, Franklin Lakes, NJ) Serum samples were separated off by centrifugation for 15 minutes at $1000 \mathrm{~g}$ (for BHBA testing within $1 / 2 \mathrm{~h}$ of collection. Haemolysed samples were excluded from the study. Serum samples were stored at $-20{ }^{\circ} \mathrm{C}$ until analysed. Samples were then centrifuged again after thawing before the BHBA analysis.

BHBA analyses were done by using $\beta$ hydroxybutyrate meter based on reflectance photometry according to manufacturer's recommendations (STATSite ${ }^{\circledR}$ M $\beta$-HB, Stanbio Laboratory, An EKF Diagnostic Company, Texas, USA). Using Stanbio STAT- Site ${ }^{\circledR}$ M $\beta$-HB test strips (4).

Blood samples for blood glucose measurement were also taken from the coccygeal vessels. One drop of collected blood was immediately dropped onto test strips of digital blood glucose meter (Optium Xceed Blood Glucose Meter, Abbott Inc, İstanbul, Turkey) and blood glucose levels were measured according to manufacturer's recommendations.

Urine sampling for the assessment of ketonuria: After collecting a blood sample, urine samples of each animal was collected by using an urethral catheter. The Combur 10 urine strip test (REF: 11379208, Cobas, Combur test, Miditron and urisys, Roche Diagnostics GmbH, Sandhofer Strasse, 116, Mannheim, GERMANY) was dip briefly (max. 1 second) into urine samples. The result was read immediately according to the colour scale provided with the test after $60 \mathrm{sec}$ and was recorded as none, light, moderate, severe based on 
the degree of purple discoloration. This test used in the study for ketone bodies is more sensitive to acetoacetic acid than to acetone and BHB.

Statistical analysis: The data were presented as mean \pm standard error (SE) in SI units. Data was analyzed using Shapiro-Wilk to determine if they are normally distributed. As the data was found to be normally distributed, student's T-test analysis by SAS software (version 9.1, SAS Inst., Inc., Cary, NC, USA) was used to show any significant differences in BHBA and glucose concentrations in the present study. Differences were considered to be significant if $\mathrm{P}<0.05$.

\section{Results}

Total 980 milking cows were used (315 milking cows in two different farms in Mediterranean region, 325 milking cows in two different farms in Aegean region, and 340 milking cows in two different farms in Marmara region) for the prevalence of clinical and sub-clinical ketosis in the study. The age of all dairy cows were ranged between 3 and 6 years old.

Routine clinic examinations including body temperature, heart rate, respiratory rate, mucosal membranes, auscultation and percussion of lungs of animals were between reference ranges in all animals with subclinical ketosis included in the study. Also, the clinical examination of mucosal and conjunctival membranes and lymph nodes of all animals were normal. No any abnormalities were detected on auscultation and percussion of lungs. The appetite of animals was normal. However, the milk yield was lower than expected in all animals with subclinical ketosis.

Although routine clinic examinations were normal in animals with clinic ketosis, these animals had significantly decreased milk production. In addition, clinical findings such as anorexia, fatigue, depression, constipation and atonia of rumen were detected in these animals with clinic ketosis.

Mean $\pm \mathrm{SE}$ of serum BHBA and glucose concentrations in cows with SCK are presented in Table 1. In this study, cows with BHBA concentrations higher than $1.2 \mathrm{mmol} / \mathrm{L}$ were classified as having SCK, and $19.4 \%$ of all tested cows had SCK. While $12.9 \%$ of the cows tested in the Aegean region, and $24.6 \%$ of the cows tested in the Marmara region had SCK, in Mediterranean region only $10.8 \%$ of the cattle were found to be suffering from SCK (Table 1) (Figure 1). Results of the Combur 10 urine strip test were negative for ketonuria in all animals with SCK. There was statistical differences $(p<0.05)$ in serum glucose levels of the healthy animals and animals that suffer from $\mathrm{CK}$ in all three regions. While serum glucose level was lower in subclinical ketosis compared with control group, it was higher in subclinical ketosis than clinical ketosis (Table 3). Mean \pm SE of serum BHBA and glucose concentrations in cows with clinical ketosis are presented in Table 2, 3 . In this study, incidence rate of clinical ketosis was determined as $8.4 \%$. While $7.05 \%$ of the cows tested in the Aegean region, $9.6 \%$ of the cows tested in the Marmara region had subclinical ketosis, incidence of clinical ketosis was found to be 3.8 percent in the Mediterranean region (Table 1) (Figure 1). BHBA concentrations of all animals affected from clinical ketosis were determined between $2.18 \mathrm{mmol} / \mathrm{l}$ and 2.78 $\mathrm{mmol} / \mathrm{l}$ (Mean $\pm \mathrm{SE} ; 2.48 \pm 0.14 \mathrm{mmol} / \mathrm{l}$ ). Also, ketonuria was severely positive in these animals detected by urine strip.

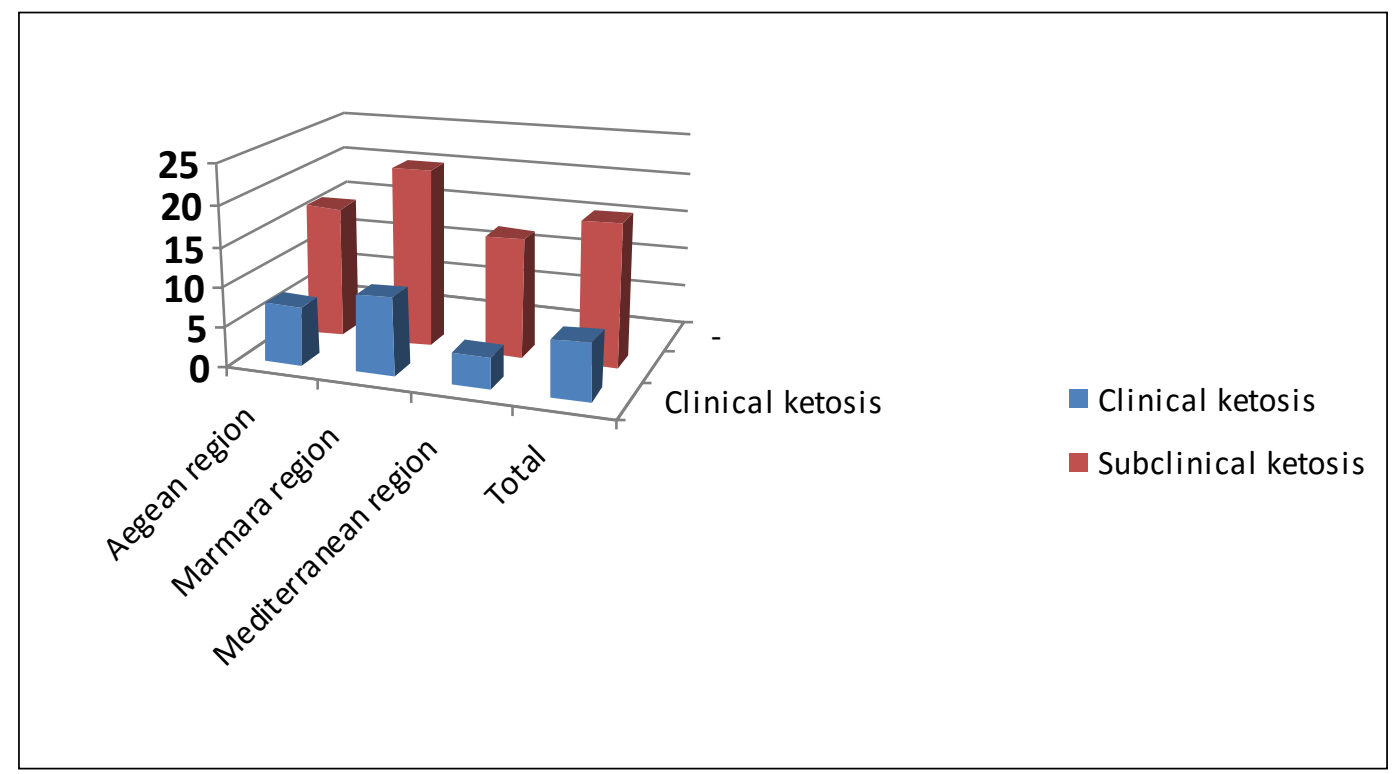

Figure 1. Incidence rates of clinical and subclinical ketosis in three regions. Şekil 1. Üç bölgedeki klinik ve subklinik ketozisin insidans oranları. 
Table 1. Distribution of clinical and subclinical ketosis according to the regions.

Tablo 1. Bölgelere göre klinik ve subklinik ketozisin dağılımı.

\begin{tabular}{lccc}
\hline & $\begin{array}{c}\text { Aegean } \\
\text { region } \\
\text { (n: 325) }\end{array}$ & $\begin{array}{c}\text { Marmara } \\
\text { region } \\
\text { (n: 340) }\end{array}$ & $\begin{array}{c}\text { Mediterranean } \\
\text { region } \\
\text { (n: 315) }\end{array}$ \\
\hline $\begin{array}{l}\text { Clinical } \\
\text { ketosis }\end{array}$ & $24(7.3 \%)$ & $33(9.7 \%)$ & $12(3.8 \%)$ \\
$\begin{array}{l}\text { Subclinical } \\
\text { ketosis }\end{array}$ & $54(16.6 \%)$ & $76(22.3 \%)$ & $46(14.8 \%)$ \\
$\begin{array}{l}\text { Cows with } \\
\text { healty }\end{array}$ & $247(76.1 \%)$ & $231(68 \%)$ & $257(81.4 \%)$ \\
\hline
\end{tabular}

Table 2. BHBA levels of healthy cows and cows with clinical and subclinical ketosis according to the regions.

Tablo 2. Bölgelere göre sağlıklı ve klinik ve subklinik ketozisli ineklerin BHBA seviyeleri.

\begin{tabular}{|c|c|c|c|}
\hline & \multicolumn{3}{|c|}{ BHBA ( Mean \pm SE) (mmol/l) } \\
\hline & $\begin{array}{l}\text { Clinical } \\
\text { Ketosis }\end{array}$ & $\begin{array}{l}\text { Subclinical } \\
\text { ketosis }\end{array}$ & $\begin{array}{l}\text { Healthy } \\
\text { cows }\end{array}$ \\
\hline $\begin{array}{l}\text { Aegean } \\
\text { region } \\
(n: 325)\end{array}$ & $\begin{array}{c}(\mathrm{n}: 24) \\
2.43 \pm 0.03 \mathrm{a}\end{array}$ & $\begin{array}{c}(\mathrm{n}: 54) \\
1.28 \pm 0.03 \mathrm{~b}\end{array}$ & $\begin{array}{c}(\mathrm{n}: 247) \\
0.39 \pm 0.42 \mathrm{c}^{* *}\end{array}$ \\
\hline $\begin{array}{l}\text { Marmara } \\
\text { region } \\
(\mathrm{n}: 340)\end{array}$ & $\begin{array}{c}(\mathrm{n}: 33) \\
2.49 \pm 0.17 \mathrm{a}\end{array}$ & $\begin{array}{c}(\mathrm{n}: 76) \\
1.29 \pm 0.15 \mathrm{~b}\end{array}$ & $\begin{array}{c}(\mathrm{n}: 231) \\
0.61 \pm 0.1 \mathrm{c}\end{array}$ \\
\hline $\begin{array}{l}\text { Mediterranean } \\
\text { region } \\
(\mathrm{n}: 315)\end{array}$ & $\begin{array}{c}(\mathrm{n}: 12) \\
2.48 \pm 0.50 \mathrm{a}\end{array}$ & $\begin{array}{c}(\mathrm{n}: 46) \\
1.27 \pm 0.47 \mathrm{~b}\end{array}$ & $\begin{array}{c}(\mathrm{n}: 257) \\
0.32 \pm 0.18 \mathrm{c} * *\end{array}$ \\
\hline $\begin{array}{l}\text { Total } \\
\text { (n:980) }\end{array}$ & $\begin{array}{c}(\mathrm{n}: 69) \\
2.46 \pm 0.2 \mathrm{a}\end{array}$ & $\begin{array}{c}(\mathrm{n}: 176) \\
1.29 \pm 0.13 \mathrm{~b}\end{array}$ & $\begin{array}{c}(\mathrm{n}: 735) \\
0.52 \pm 0.1 \mathrm{c}^{* *}\end{array}$ \\
\hline
\end{tabular}

Table 3. Glucose levels of healthy cows and cows with clinical and subclinical ketosis according to the regions.

Tablo 3. Bölgelere göre sağlıklı inekler ve klinik ve subklinik ketozisli ineklerin glukoz seviyeleri.

\begin{tabular}{lccc}
\hline \multicolumn{4}{c}{ Glucose $($ Mean \pm SE) $(\mathrm{mg} / \mathrm{dl})$} \\
\hline & $\begin{array}{c}\text { Clinical } \\
\text { Ketosis }\end{array}$ & $\begin{array}{c}\text { Subclinical } \\
\text { ketosis }\end{array}$ & $\begin{array}{c}\text { Healthy } \\
\text { cows }\end{array}$ \\
\hline $\begin{array}{l}\text { Aegean } \\
\text { region } \\
(\mathrm{n}: 325)\end{array}$ & $\begin{array}{l}(\mathrm{n}: 24) \\
(\mathrm{n}: 54)\end{array}$ & $(\mathrm{n}: 247)$ \\
$\begin{array}{l}\text { Marmara } \\
\text { region } \\
\text { (n:340) }\end{array}$ & $46.2 \pm 1.1 \mathrm{a}$ & $50.2 \pm 2.2 \mathrm{~b}$ & $70.1 \pm 2.5^{* *}$ \\
$\begin{array}{l}\text { Mediterranean } \\
\text { region }\end{array}$ & $(\mathrm{n}: 33)$ & $(\mathrm{n}: 76)$ & $(\mathrm{n}: 231)$ \\
$(\mathrm{n}: 315)$ & $45.1 \pm 3.1 \mathrm{a})$ & $51.7 \pm 2.9 \mathrm{~b}$ & $66.5 \pm 1.3^{* *}$ \\
$\begin{array}{l}\text { Total } \\
(\mathrm{n}: 980)\end{array}$ & $(\mathrm{n}: 69)$ & $(\mathrm{n}: 176)$ & $(\mathrm{n}: 735)$ \\
\hline & $44.8 \pm 2.2 \mathrm{a}$ & $51.6 \pm .2 .3 \mathrm{~b}$ & $68.3 \pm 1.8^{* *}$ \\
\hline
\end{tabular}

**P< 0.01 a,b,c: Differences between the values involving different letters on the same row are found to be statistically significant.
Serum glucose levels were lower in animals with clinical ketosis according to healthy and cows with subclinical ketosis (Table 3 ) in all three regions.

\section{Discussion and Conclusion}

During lactation, even towards the end of the pregnancy period, energy consumption of dairy cows is increased. If this energy is not compensated, it is the inevitable occurrence of ketosis $(13,14,21)$. Ketosis is a metabolic disorder that occurs as subclinical and clinical forms. Clinical and subclinical ketosis are both characterized by reduced milk yield, impaired reproductive efficiency and increased secondary diseases such as metritis, mastitis, abomasal displacement. Therefore, both clinical and subclinical ketosis causes significant economic losses. So, determination and close monitoring of the incidence of clinical and subclinical ketosis in dairy cows is very important. According to the results of the incidence of clinical and subclinical ketosis, more accurate methods of prevention can be created.

In this study, we aimed to determine the incidence of primary clinical and subclinical ketosis in large dairy farms in Turkey. For the protection of ketosis, the results obtained here also will give direction for the feeding and care, especially in transition period.

The incidence of clinical ketosis has been evaluated by some authors, and were reported to be between $1.1 \%$ and $9.2 \%(15,24)$. However, some studies $(5,12,15)$ had been reported that the prevalence of subclinical ketosis has been varied between $12 \%$ and $34 \%$. Suthar et al. (31) reported that maximum and minimum prevalence of subclinical ketosis were 36.6 and $11.2 \%$ in Italy and Turkey respectively (31). In terms of clinical ketosis, the same researchers have determined the rates as 0.4 and $11.1 \%$ for Hungary and Italy respectively. In addition, the prevalence of clinical ketosis in Turkey has been found as $2 \%$ in the same study (31). Findings of the researchers clearly demonstrated that prevalence of subclinical and clinical ketosis were lower in Turkey (31). The incidence of subclinical and clinical ketosis in Turkey was determined to be higher in the present study. These differences in studies may be related to the different care and feeding habits of animals. In regional assessments, while $12.9 \%$ of the cows tested in the Aegean region and $24.6 \%$ of the cows tested in the Marmara region had subclinical ketosis, this rate was found to be 10.8 percent in the Mediterranean region. As seen, subclinical ketosis rate was higher in the Marmara region than the other two regions. In the present study, the rates of clinical ketosis in all animals were found to be $8.4 \%$. As in subclinical ketosis, Marmara region has the highest rate of clinical ketosis. Probably, higher rates of subclinical and clinical ketosis in the Marmara region 
were due to errors in management and feeding of the animals; particularly the transition period errors.

The most important diagnostic test for subclinical ketosis is the measurement of BHB in blood (10). To distinguish between normal cows and cows with abnormal levels of BHB, a threshold value of $1200 \mu \mathrm{mol} / \mathrm{L}$ is recommended (23). Some dairy cows can have high ketone bodies without obvious clinical signs $(2,8,25)$. Although BHBA blood level is $>1.2 \mathrm{mmol} / \mathrm{l}$, perhaps the only reflection is a reduction in milk yield. As it noted in some studies (2), these cows are termed as subclinical ketosis. In the present study, cows with high BHBA (serum BHBA >1.2 mmol/l) without obvious clinical symptoms were selected as subclinical ketosis. In the present study, for subclinical ketosis, BHBA value has been determined as $1.29 \pm 0.13 \mathrm{mmol} / 1$ (mean $\pm \mathrm{SE}$ ) in cows in Marmara, Aegean and Mediterranean regions. There was no statistically significant difference between regions. BHBA levels determined in the present study for subclinical ketosis were similar to previous reports $(8$, $11,15,16,19)$.

BHBA is the most important test in the diagnosis of ketosis $(18,21)$. Andersson (1) reported that subclinical ketosis may start at serum BHB concentrations above $1000 \mu \mathrm{mol} / \mathrm{L}$ and clinical ketosis at about $2600 \mu \mathrm{mol} / \mathrm{L}$; however, at exactly what level individual cows will express clinical signs is extremely variable. In the present study, the BHBA levels for clinical ketosis were measured between $2.18 \mathrm{mmol} / \mathrm{l}$ and $2.78 \mathrm{mmol} / \mathrm{l}$. These values were greater than in previous reports $(23,31)$. In the present study, for clinical ketosis, BHBA value has been determined as $2.49 \pm 0.17,2.43 \pm 0.03$ and $2.48 \pm 0.50$ $\mathrm{mmol} / \mathrm{l}$ in cows in Marmara, Aegean and Mediterranean regions respectively. There was no statistically significant difference between regions. BHBA values of cows in three different regions were similar for clinical ketosis. As seen in the present study, clinical ketosis has a value greater than subclinical ketosis.

Hypoglycemia occurs in varying degrees in primary ketosis (16). However, Asl et al. (3) report that evaluation of serum glucose levels may be not important for the diagnosis of subclinical ketosis and monitoring subclinical ketosis. Hypoglycemia is more severe in clinical ketosis when compared with subclinical. Similarly, the serum glucose values were significantly lower in animals with clinical ketosis when compared to subclinical ketosis in the present study. Also, in our study, serum glucose levels were significantly lower in animals with subclinical and clinical ketosis when compared with healthy cows.

In conclusion, subclinical and clinical ketoses are not different diseases. Both of them are metabolic problems caused by negative energy balance. In particular, subclinical ketosis in dairy cattle has become a major problem nowadays. In the present study, obtained data shows that this problem exists in Turkey. It is well known that the negative energy balance increases the risk of diseases such as; mastitis, metritis, milk fever, retained plecanta and displaced abomasum $(6,11,18,24,30,31)$. Thus, negative energy balance causes significant economic losses. For minimization of such losses, monitoring energy metabolism in a regular basis by evaluation of biochemical parameters such as BHBA, NEFA and glucose is important. In line with the results obtained, especially the transition period feeding should be rearranged.

\section{References}

1. Andersson L (1984): Concentration of blood and milk ketone bodies, blood isopropanol and plasma glucose in dairy cows in relation to the degree of hyperketonaemia and clinical signs. Zentralbl Veterinarmed A, 31, 683-693.

2. Andersson L (1988): Sub-clinical ketosis in dairy cows. Vet Clin North Am Food Anim Pract, 4, 233-251.

3. Asl AN, Nazifi S, Ghasrodashti AR, et al. (2011): Prevalence of subclinical ketosis in dairy cattle in the Southwestern Iran and detection of cutoff point for NEFA and glucose concentrations for diagnosis of subclinical ketosis. Prev Vet Med, 100, 38-43.

4. Demir G, Mecitoglu Z, Catik S, et al. (2012): Comparison of two cow side BHBA test for diagnosis of subclinical ketosis. Uludag Univ J Fac Vet Med, 31, 7-10.

5. Dohoo IR, Martin SW (1984a): Disease, production and culling in Holstein-Friesian cows IV. Effects of disease on production. Prev Vet Med, 2, 755-770.

6. Dohoo IR, Martin SW (1984b): Subclinical ketosis: Prevalence and associations with production and disease. Can J Comp Med, 48, 1-5.

7. Dubuc J, Duffield TF, Leslie KE, et al. (2010): Risk factors for postpartum uterine diseases in dairy cows. J Dairy Sci, 93, 5764-5771.

8. Duffield TF, Sandals D, Leslie KE, et al. (1998): Efficacy of monensin for the prevention of subclinical ketosis in lactating dairy cows. J Dairy Sci, 81, 2866-2873.

9. Duffield TF, Leslie KE, Sandals D, et al. (1999): Effect of a monensin controlled-release capsule on cow health and reproductive performance. J Dairy Sci, 82, 2377-2384.

10. Duffield T (2000): Subclinical ketosis in lactating dairy cattle. Vet Clin North Am Food Anim Pract, 16, 231-253.

11. Duffield TF, Lissemore KD, McBride BW, et al. (2009): Impact on hyperketonemia in early lactation dairy cows on health and production. J. Dairy Sci, 92, 571-580.

12. Geishauser T, Leslie $\mathbf{K}$, Tenhag J, et al. (2000): Evaluation of eight cow-side ketone tests in milk for detection of subclinical ketosis in dairy cows. J Dairy Sci, 83, 296-299.

13. Goff JP, Horst RL (1997): Effects of the addition of potassium or sodium, but not calcium, to prepartum rations on milk fever in dairy cows. J Dairy Sci, 80, 176186. 
14. Herdt TH, Emery RS (1992): Therapy of diseases of ruminant intermediary metabolism. Vet Clin North Am Food Anim Pract, 8, 91-106.

15. Kauppinen K (1983): Correlation of whole blood concentrations of acetoacetate, 8-hydroxybutyrate, glucose and milk yield in dairy cows as studied under field conditions. Acta Vet Scand, 24, 349-361.

16. Kennerman E, Sentürk S, Biricik H (2006): Effect of monensin controlled release capsules on blood metabolites in periparturient dairy cows. Aust Vet J, 84, 282-284.

17. Kremer WDJ, Burvenich C, Noordhuizen-Stassen EN, et al. (1993): Severity of experimental Escherichia coli mastitis in ketonemic and non-ketonemic dairy cows. $\mathrm{J}$ Dairy Sci, 76, 3428.

18. LeBlanc S (2010): Monitoring metabolic health of dairy cattle in the transition period. J Reprod Dev, 56, 29-35.

19. LeBlanc SJ, Leslie KE, Duffield TF (2005): Metabolic predictors of displaced abomasum in dairy cattle. J Dairy Sci, 88, 159-170.

20. Mc Art JA, Nydam DV, Oetzel GR, et al. (2013): Elevated non-esterified fatty acids and $\beta$-hydroxybutyrate and their association with transition dairy cow performance. Vet J, 198, 560-70.

21. Nielsen NI, Ingvartsen KL (2004): Propylene glycol for dairy cows A review of the metabolism of propylene glycol and its effects on physiological parameters, feed intake, milk production and risk of ketosis. Anim Feed Sci Tech, 115, 191-213.

22. Oetzel GR (2004): Monitoring and testing dairy herds for metabolic disease. Vet Clin North Am Food Anim Pract, 20, 651-674.

23. Ospina PA, Nydam DV, Stokol T, et al. (2010): Evaluation of nonesterified fatty acids and $B$ hydroxybutyrate in transition dairy cattle in the northeastern United States: Critical thresholds for prediction of clinical diseases. J Dairy Sci, 93, 546-554.
24. Østergaard S, Gröhn YT (2000): Concentrate feeding, dry-matter intake, and metabolic disorders in Danish dairy cows. Livest Prod Sci, 65, 107-118.

25. Roberts T, Chapinal N, LeBlanc SJ, et al. (2012): Metabolic parameters in transition cows as indicators for early-lactation culling risk. J Dairy Sci, 95, 3057-3063.

26. Rollin E, Berghaus RD, Rapnicki P, et al. (2010): The effect of injectable butaphosphan and cyanocobalamin on postpartum serum B-hydroxybutyrate, calcium, and phosphorus concentrations in dairy cattle. J Dairy Sci, 93, 978-987.

27. Ruegg PL (2003): Investigation of mastitis problems on farms. Vet Clin North Am Food Anim Pract, 19, 47-73.

28. Schukken H (2000): Hyperketonemia and the impairment of udder defense: A review. Vet Res, 31, 397-412.

29. Seifi HA, LeBlanc SJ, Leslie KE, et al. (2011): Metabolic predictors of post-partum disease and culling risk in dairy cattle. Vet J, 188, 216-220.

30. Senturk S, Mecitoglu Z, Temizel EM, et al. (2010): Clinical and biochemical evaluation of cows occuring severe weight loss after calving. Uludag Univ J Fac Vet Med, 29, 43-49.

31. Suthar VS, Canelas-Rapos J, Deniz A, et al. (2013): Prevalence of subclinical ketosis and relationships with postpartum diseases in European dairy cows. J Dairy Sci, 96, 2925-38.

Geliş tarihi: 05.06.2015 / Kabul tarihi: 12.10.2015

Address for correspondence:

Sezgin Şentürk, DVM, PhD, Prof. D

Uludag University, Faculty of Veterinary Medicine,

Department of Internal Medicine, Gorukle Campus, 16059

Gorukle, Bursa, Turkey.

e-mail:sezsen@uludag.edu.tr 